\title{
Laparoscopic management of hydatid cysts with biliary communication: clips may rescue when suture fails - report of three cases
}

\author{
Saket Kumar ${ }^{1}$, Rugved Kulkarni ${ }^{1}$, Nikhil Chopra ${ }^{1}$, Abhijit Chandra ${ }^{1}$ \\ 1 Department of Surgical Gastroenterology, King George's Medical University School of Medicine, Lucknow, India
}

\begin{abstract}
Hydatid disease is a parasitic zoonosis caused by the larval form of the Echinococcus worm. Hepatic hydatidosis is the most common form of the disease in humans. Centrally located, large hydatid cysts have the tendency to rupture into the adjoining bile duct and form a fistulous communication. Suture closure of the cysto-biliary communication detected during surgery is recommended to avoid postoperative complications related to bile leak. In the era of minimally invasive surgery, laparoscopic management of the cysto-biliary communication can be challenging, and laparoscopic suturing may not always be feasible. Postoperative endoscopic biliary decompression is necessary in such situations, but it has its own set of potential risk and complications. This case report aimed at presenting a simple and easy technique for laparoscopic closure of the cysto-biliary communication when suture ligation is technically not possible.
\end{abstract}

Keywords: Hydatid cyst, laparoscopic, cysto-biliary communication, clipping, bile leak

Cite this article as: Kumar S, Kulkarni R, Chopra N, Chandra A. Laparoscopic management of hydatid cysts with biliary communication: clips may rescue when suture fails-report of 3 cases. Turk J Surg 2019; 35 (3): 227-230.

\section{Corresponding Author}

Abhijit Chandra

E-mail: abhijitchandra@hotmail.com

Received: 28.01.2018

Accepted: 09.02.2018

Available Online Date: 20.11.2018

OCopyright 2019 by Turkish Surgical Society Available online at www.turkjsurg.com

DOI: $10.5578 /$ turkjsurg.4107

\section{INTRODUCTION}

Echinococcal hydatid disease is a parasitic zoonosis endemic in the Indian subcontinent. The liver is the most commonly affected organ (50\%-70\%), but other organs such as the lungs, spleen, and brain can also be involved $(1,2)$. Cysto-biliary communication (CBC) is the most common complication of hepatic hydatid cyst, and its management may pose a challenge during minimally invasive surgery (3). Suture ligation of any detectable CBC is advised; however, it may not always be possible (4).

This study aimed at reporting three cases of hepatic hydatid cyst in whom CBC was detected intraoperatively, but laparoscopic suture ligation was not feasible. Laparoscopic clip application was performed to occlude $C B C$, thus avoiding the need for conversion (to open surgery) or any postoperative intervention.

\section{CASE REPORTS}

Case 1

A 62-year-old man presented with complaints of discomfort in the right hypochondrium for one month. There was no associated nausea, vomiting, jaundice, or weight loss. General examination of the patient was unremarkable. On abdominal examination, a globular, non-tender lump was palpable in the right hypochondrium. Blood investigations including liver function tests were normal. Abdominal computed tomography (CT) revealed a hydatid cyst size of $12 \times 11 \times 16 \mathrm{~cm}$ involving the left lobe of the liver extending up to the perihilar region (Figure 1).

Laparoscopic hydatid cyst deroofing was performed, and daughter cysts and hydatid sand were evacuated. A small $(5 \mathrm{~mm}$ ) CBC with ongoing bile leak was discovered in the cyst cavity. Laparoscopic suturing of the CBC was attempted; however, it was unsuccessful due to the difficult fistula site. Metallic clips were applied to occlude CBC (Figure 2). Postoperative course was uneventful with no bile leak. The patient remained symptom-free at three months follow-up. 


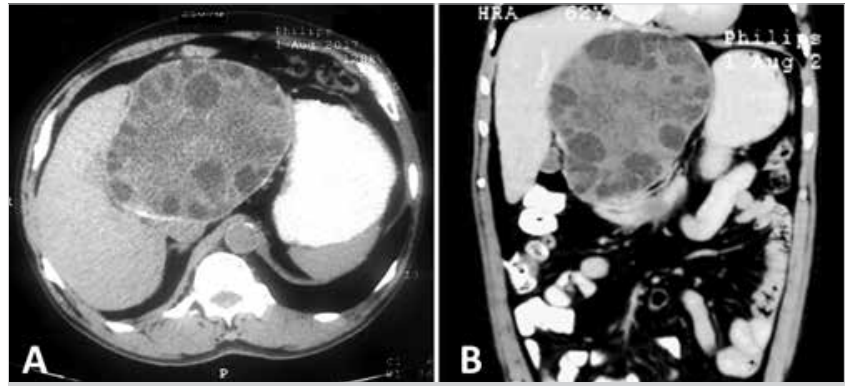

Figure 1. Computed tomography scan of the abdomen showing a large hepatic hydatid cyst in close relation to the hilum.
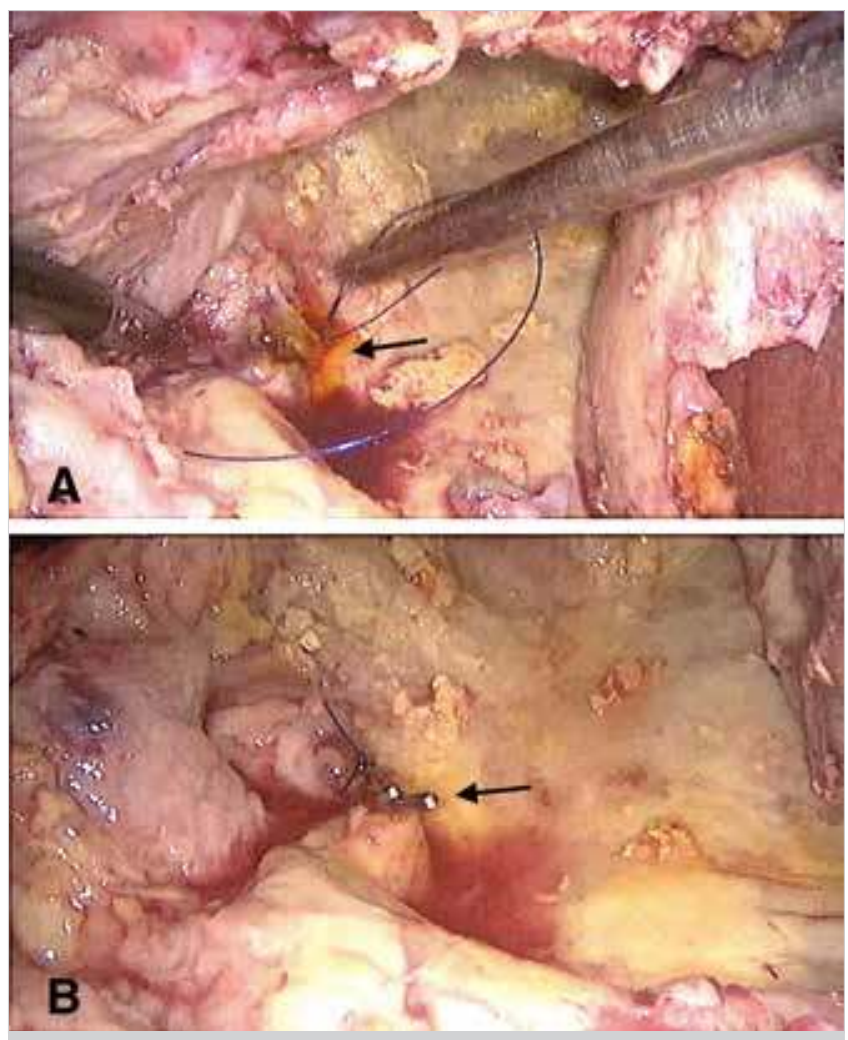

Figure 2. Laparoscopic image showing bile leak from a cysto-biliary fistula. Suture ligation is being attempted (A). Application of metallic clips successfully occluded the fistula (B).

\section{Case 2}

A 65-year-old woman presented with complaints of upper abdominal pain for two years with no other relevant history. General examination of the patient was unremarkable. On abdominal palpation, a tender hepatomegaly was found. Hemogram and bilirubin level were normal; however, serum alkaline phosphatase level (440 IU/L) was elevated. CT scan revealed two hydatid cysts in segments $\mathrm{VI}$ and VIII (sizes $7 \times 6 \times 6 \mathrm{~cm}$ and $4 \times 4 \times 6$ $\mathrm{cm}$, respectively) of the liver lying in close proximity to the right biliary system (Figure 3). Magnetic resonance cholangiopancreatogram showed a dilated common bile duct (14 mm) with intraluminal filling defects and a $9 \mathrm{~mm}$ focal defect in the poste-

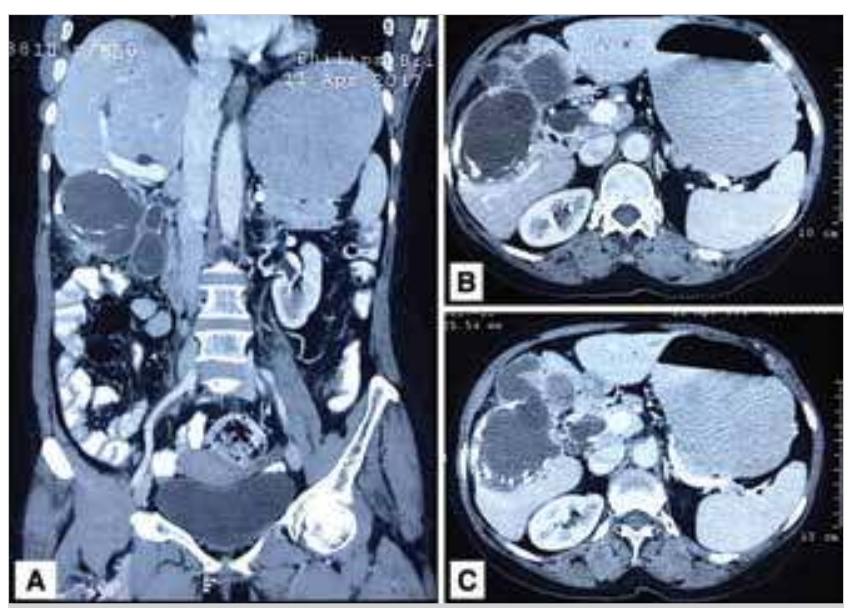

Figure 3. Computed tomography scan showing two hydatid cysts in segments VI and VIII of the liver lying in close proximity to the right biliary system (A). Coronal section view. Transverse section view (B,C).

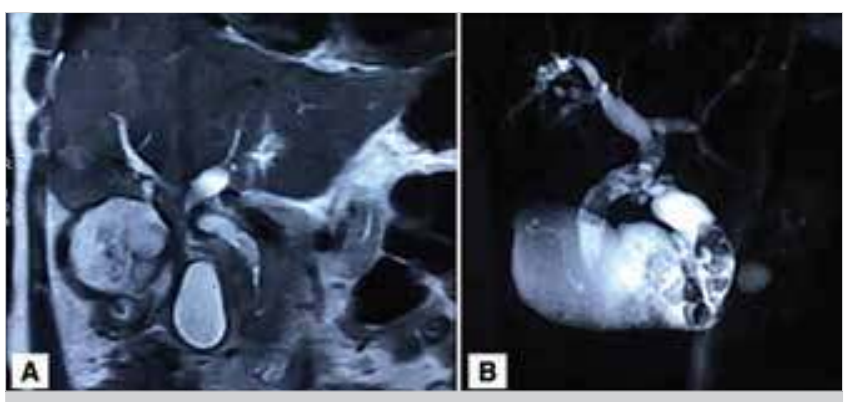

Figure 4. Magnetic resonance image of the abdomen showing hydatid cyst in segment VI of the liver lying in close proximity to the bile duct (A). Magnetic resonance cholangiopancreatogram showing dilated biliary system with filling defects (daughter cysts) in the common bile duct (B).

rior cyst wall, suggesting CBC (Figure 4). Endoscopic retrograde cholangiopancreatogram (ERCP) was planned for biliary decompression in view of a possible CBC, followed by laparoscopic hydatid cyst management. At ERCP, cholangiogram revealed few filling defects in CBC. On balloon sweep, few membranes were cleared from the $\mathrm{CBC}$, and a $10 \mathrm{Fr}$ plastic stent was placed in the right biliary system. Cyst contents were bile stained intraoperatively (Figure 5), and a CBC was present in the segment VI cyst. Laparoscopic suturing was not possible due to the limited intracavitary space. Finally, clips were applied laparoscopically, and the CBC was occluded. The patient recovered well and remained symptom-free six months post-surgery. An informed consent for publication was obtained from all three patients discussed in this study.

\section{Case 3}

A 35-year-old woman was admitted for pain in the right hypochondrium and nausea for three months. General examination and her abdominal findings were normal except for a small paraumbilical hernia. Blood investigations (including liver function 


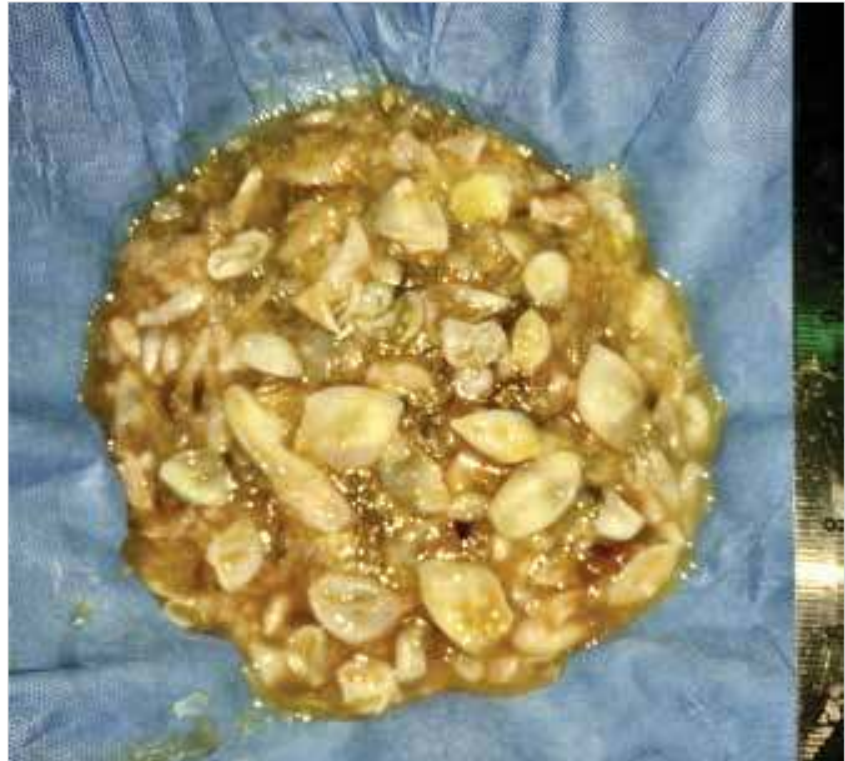

Figure 5. Bile stained hydatid cyst contents, suggesting a cysto-biliary fistula.

tests) were within normal limits. Abdominal CT demonstrated a hydatid cyst size of $9.5 \times 7.4 \times 7 \mathrm{~cm}$ in relation to segment $\mathrm{VI}$ of the liver. Laparoscopic hydatid cyst surgery and paraumbilical hernia repair were performed in a single setting. A small $(5 \mathrm{~mm})$ CBC was noted along the medial Wall of the cyst cavity intraoperatively. Laparoscopic suturing of the CBC was attempted but could not be performed due to the difficult location of the CBC. Laparoscopic endoclipping of the CBC was performed with metallic clips. She had an uneventful postoperative course and remained symptom-free at eight months follow-up.

\section{Technique}

Between 2009 and 2017, 54 cases of laparoscopic hydatid cyst deroofing were performed in our center out of which intraoperative CBC was detected in 20 patients. Laparoscopic suturing was performed in 12 cases, open surgery in three cases, and postoperative biliary stenting in two patients. Laparoscopic clip occlusion was performed in the above three cases.

CBC site was clearly delineated after deroofing and evacuation of the cyst contents. The fistula site was grasped with a tip of a Maryland dissector and lifted slightly. Two metal clips (Ligaclip Extra, Ethicon Endo-surgery, LLC, Guaynabo, Puerto Rico, USA) were then applied over the fistula site. Cessation of the bile leak indicated successful occlusion of the fistula (Supplementary video file 1). A surgical vacuum drain was placed in all three cases.

\section{DISCUSSION}

Hepatic hydatid disease is a significant problem in endemic areas including India (1-3). The cyst gradually enlarges and compresses the surrounding hepatocytes and biliary radicles. Long standing bile duct compression by the hydatid cyst may result in intrabiliary cyst rupture, leading to the formation of CBC (5). CBC incidence has been reported in up to $25 \%-30 \%$ of cases (1-3). Diagnosis of CBC is usually made preoperatively, but sometimes, it can get unmasked during surgery. Occult $C B C$ remains undetected even during surgery and is manifested in the postoperative period as biloma or external biliary fistula (6). Postoperative management of such leaks is challenging and may require invasive procedures, such as endoscopic biliary stenting and percutaneous drain placement. A major laparotomy may rarely become necessary. Thus, intraoperative detection and management of CBC are crucial.

Preoperative factors indicating the likelihood of CBC include deranged liver function tests (increased bilirubin or alkaline phosphatase level), leukocytosis $\left(>10.000 \mathrm{~mm}^{3}\right)$, perihilar or central location, large size $(>10 \mathrm{~cm})$, and dilated biliary radicles on imaging $(7,8)$. Infrequently, it may be delineated on CT or magnetic resonance imaging (9).

All CBCs detected intraoperatively should be meticulously addressed. With the advent of minimally invasive approaches, laparoscopic hydatid cyst deroofing is increasingly performed offering several advantages (10). However, management of concomitant CBC can sometimes be challenging with this approach. Difficult fistula site, limited intracavitary space, and surgeon's inexperience may occasionally render laparoscopic CBC suturing unachievable. In all three of our cases, laparoscopic suture ligation was not possible due to the difficult location and limited access. Metal clips were applied, and bile leak stopped instantaneously, thus avoiding any postoperative morbidity and need of postoperative ERCP. Clip slippage is a potential drawback; however, no such complication was encountered in the present case series.

\section{CONCLUSION}

Laparoscopic suturing of CBC encountered during hydatid cyst surgery may be technically challenging. Laparoscopic clipping can successfully occlude CBC in difficult cases. It is a cheap, reproducible and effective technique of $\mathrm{CBC}$ management.

Informed Consent: Written informed consent was obtained from patient who participated in this study.

Peer-review: Externally peer-reviewed.

Author Contributions: Concept - S.K., A.C.; Design - S.K., A.C., N.C., R.K.; Supervision - S.K., A.C.; Resource - R.K., N.C.; Materials - S.K., R.K., A.C.; Data Collection and/or Processing - S.K., R.K., N.C., A.C.; Literature Search - S.K., R.K., N.C.; Writing Manuscript - S.K., R.K., N.C.; Critical Reviews - S.K., A.C.

Conflict of Interest: The authors have no conflicts of interest to declare.

Financial Disclosure: The authors declared that this study has received no financial support. 


\section{REFERENCES}

1. Saritas U, Parlak E, Akoglu M, Sahin B. Effectiveness of endoscopic treatment modalities in complicated hepatic hydatid disease after surgical intervention. Endoscopy 2001; 10: 858-63. [CrossRef]

2. Sciume C, Geraci G, Pisello F, Li Volsi F, Facella T, Modica G. Treatment of complications of hepatic hydatid disease by ERCP: our experience. Ann Ital Chir 2004: 5: 531-5.

3. Langer JC, Rose DB, Keystone JS, Taylor BR, Langer B. Diagnosis and management of hydatid disease of the liver. A $15 y$ ear North American experience. Ann Surg 1984; 199: 412-7. [CrossRef]

4. Bains L, Gautam KK, Vin dal A, Lal P. Biliary duct communication in massive hepatic hydatidosis managed with minimally invasive techniques. MAMC J Med Sci 2015; 1: 37-40. [CrossRef]

5. El Nakeeb A, Salem A, El Sorogy M, Mahdy Y, EllatifMA, Moneer A, et al. Cystobiliary communication in hepatic hydatid cyst: predictors and outcome. Turk J Gastroenterol 2017; 28: 125-30. [CrossRef]
6. Demircan O, Baymus M, Seydaoglu G, Akinoglu A, Sakman G. Occult cystobiliary communication presenting as postoperative biliary leakage after hydatid liver surgery: Are there significant preoperative clinical predictors? Can J Surg 2006; 49: 177-84.

7. Kilic M, Yoldas O, Koc M, Keskek M, Karakose N, Ertan T, et al. Can biliary-cyst communication be predicted before surgery for hepatic hydatid disease: does size matter? Am J Surg 2008; 196: 732-5. [CrossRef]

8. Unalp HR, Baydar, Kamer E, Yilmaz Y, Issever H, Tarcan E. Asymptomatic occult cysto-biliary communication without bile into cavity of the liver hydatid cyst: a pitfall in conservative surgery. Int I Surg 2009; 7: 387-91. [CrossRef]

9. Kumar R, Reddy SN, Thulkar S. Intrabiliary rupture of hydatid cyst: diagnosis with MRI and hepatobiliary isotope study. Br J Radiol 2002; 75: 271-4. [CrossRef]

10. Tuxun T, Zhang JH, Zhao JM, Tai QW, Abudurexti M, Ma HZ, et al. World review of laparoscopic treatment of liver cystic echinococcosis-914 patients. Int J Infect Dis 2014; 24: 43-50. [CrossRef]

\section{OLGU SERISI-ÖZET \\ Turk J Surg 2019; 35 (3): 227-230}

\section{Safra yolları ile ilişkili hidatik kistlerinin laparoskopik tedavisi: dikişler başarısız olduğunda klipler faydalı olabilir - üç olgu sunumu}

Saket Kumar ${ }^{1}$, Rugved Kulkarni ${ }^{1}$, Nikhil Chopra ${ }^{1}$, Abhijit Chandra ${ }^{1}$

1 King George's Üniversitesi Tıp Fakültesi, Cerrahi Gastroenteroloji Bölümü, Lucknow, Hindistan

\section{ÖZET}

Hidatik hastalık, Echinococcus solucanının larval formunun neden olduğu parazit bir zoonozdur. Hepatik hidatidoz insanlardaki en yaygın formdur. Merkezi yerleşimli büyük hidatik kistler, bitişik safra kanalına rüptür olma eğilimi gösterir ve fistül bir iletişim oluşturur. Safra sızıntısı ile ilişkili postoperatif komplikasyonları önlemek için, cerrahi sırasında tespit edilen sistobiliyer bağlantıların sütür ile kapatılması önerilir. Laparoskopik yöntem ile sistobiliyer müdahale zor olabilir ve laparoskopik dikiş her zaman uygun olmayabilir. Bu gibi durumlarda postoperatif endoskopik safra dekompresyonu gerekir, ancak bunun da kendi potansiyel risk ve komplikasyonları vardır. Bu çalışmada, dikiş ligasyonunun teknik olarak mümkün olmadığında sistobiliyer bağlantıların laparoskopik yöntemle kapatılması için basit ve kolay bir teknik sunmaktayız.

Anahtar Kelimeler: Hidatik kist, laparoskopik, sistobiliyer iştirak, klipleme, safra kaçağı

Doi: 10.5578/turkjsurg.4107 